\title{
The impact assessment of technologies diffusion: a mixed methods analysis
}

\author{
Kurosh Rezaei-Moghaddam ${ }^{*}$ and Somayeh Tohidyan Far
}

\begin{abstract}
Background: Impact assessment is an important process that helps the policy makers to understand the consequences of possible and actual government interventions. Assessing the impacts and consequences is considered as applicable means for policy makers and planners of projects, since not only it measures and presents the plans' developments, but also for determining their impacts on the target group. Therefore, the purpose of this paper was to assess the impacts of laser-land-leveling technology in Iran, comparing the impacts among two groups of farmers adopting traditional-leveling and laser-land-leveling projects and identifying factors influencing perception regarding laser-land-leveling technology impacts.

Methodology: The research draws on a mixed-methods approach, which includes two distinct research phases. First, 375 farmers were selected using survey based on stratified random sampling for quantitative part. Twenty-Seven farmers were also interviewed in the qualitative phase.

Results: The most important impacts of laser-land leveling were uniform germination of the crop, uniform distribution of water, decrease of soil erosion, increasing positive competition, and increasing net income. In addition, the results revealed that adopters of laser-land leveling expressed more impacts than another group.

Conclusions: Attitude towards water and soil resources' conservation was the most important variable to predict the impacts' perception among traditional-leveling adopters. It is necessary to officials to increase the information of farmers regarding different consequences of the project and contributing them to make proper decisions for farm management.
\end{abstract}

Keywords: Laser-land leveling, Impact assessment, Mixed methods, Structural equation model, Attitude, Soil conservation

\section{Introduction}

Agriculture is a vital sector of Iran's economy [26]. Growth of agriculture depends upon improving the efficiency of resources and production resources by developing infrastructures, agricultural new methods, and technologies. If different social, cultural, and environmental problems are not taken into consideration during agricultural development plans, economic growth resulting from agricultural development plans will not resolve the critical problems, but intensify it.

Nowadays, environmental degradation in Iran has drawn the attention of many agricultural scientists and

*Correspondence: dr.rezaeimoghaddam@gmail.com; rezaei@shirazu.ac.ir Department of Agricultural Extension and Education, School of Agriculture, Shiraz University, Shiraz, Iran specialists towards sustainable agricultural systems [38]. Identifying and assessing the impacts of plans are needed for managing, maximizing benefits and minimizing negative impacts towards sustainable development. Executing these plans in Iran is not formulated well and the impacts are not reduced, so Iran suffers from environmental degradation and social disorders of the plans in many regions. Then, many agricultural development plans in Iran are criticized, because social and environmental impacts are not considered [29]. Impacts' assessment of agricultural technologies is important for sustainable development, because the interaction of technology, environment, and society with its multiple interests and objectives may result in non-intentional, indirect, and delayed impacts [32]. 
Laser-land leveling is an appropriate plan for water, soil, and agricultural products' management [31]. Imprecision and inability of mechanical systems controlled by human senses cause inappropriate quality for gravity irrigation in lands and unevenness in the water resources are exposed to the danger of being salty and inexistence by making high cretes, destroying prior leveling and overconsuming water.

Since 2004, traditional (mechanical) systems have been replaced by laser-land leveling for proper efficiency and precision, increasing the productivity of water and soil resources, conserving soil, providing a balance in underground water resources, increasing farming products, decreasing the consumption of chemical fertilizers and agricultural pesticides, performing water and soil infrastructure rapidly, and preserving agricultural products health standards [11]. Implementation of laser-land leveling and traditional-land-leveling projects has different impacts on stakeholders and villagers. These impacts are outlooks of human activities and can indicate the weaknesses and strengths of the projects. Identifying these impacts and consequences would be valuable for managers of these plans. To measure and present the plans' developments and determine their impacts on the target group. Thus, the introduction and implementation of laser-land-leveling technology as a replacement for mechanical systems in Iran show that comprehensive studies are required for assessing the impacts.

Various studies have reported the impacts of laserland-leveling project. Decreasing the amount of water consumption, uniform distribution of water, reducing irrigation frequency, and time and water wasting is among the most important impacts $[1,5,9,16,19,22$, 36]. Gonzalez et al. [16]; Abdullaev et al. [1], [19, 20] have asserted that laser-land leveling causes the reduction of pesticides consumption, improves use of soil nutritious, and reduces chemical fertilizers consumption. Jat et al. [19] noted that amount of fuel consumed by water pumping and agricultural machinery would be reduced by laser-land leveling. The results of Rickman [31] revealed that the required time for planting seed was decreased after laser-land leveling. Jat et al. [19] and Rickman [31] showed that farmers consider their cretes in bigger sizes by the laser-land-leveling technology. In addition, laserland leveling led to increase the cultivable area (farm useful area) and under-cultivated area based on accessible water supply. Different studies have confirmed that laser-land leveling will decrease farming costs in different cultivation and harvest stages $[1,17]$. Abdullaev et al. [1]; Jat et al. [19], and Rickman [31] indicated that farmers' income will be increased by leveling lands. Abdullaev et al. [1] and Akhtar [3] concluded that one of the impacts of lands leveling is reducing family workforce and number of labours needed for different farming operations.
Reducing weeds, pests, and plant diseases are considered as other advantages of this technology [16, 19, 31]. Gonzalez et al. [16] reported that reduction in soil erosion is due to the implementation of laser-land-leveling project.

The studies mostly reported technical and economic impacts of the project, but paid less attention to social and environmental aspects. Therefore, social and environmental aspects are required in laser-land-leveling process to achieve a sustainable development in rural areas. Environmental impact assessment (EIA) and social impact assessment (SIA) are proposed for assessing the impacts of the plans [30]. Gilpin [14] believes that "EIA is the official appraisal of the likely effects of a proposed policy, program or project on the environment; alternative to the proposal; and measures to be adopted to protect the environment". "Environmental Impact Assessment is a systematic process through which the effects of development plans can be identified and evaluated in advance" [15]. The main aim of EIA is to determine the direct impacts of the proposed activity, with an emphasis on the environmental consequences and submit these results to decision makers. This is with the purpose of ensuring that development only proceeds in an acceptable manner [21]. There have been different indices for EIA [10, 24, 32]. Environmental impacts refer to variations that will be made as a result of different activities in physical environment (climate, land, and soil), ecology (quality and quantity of surface water, air, sound, and soil), biology (animal and plants species, sensitive environmental areas, natural habitats, and diseases' vectors), and social economy (population, education, specialty, income, facilities, employment, sanitation, health, views, and landscape) [28].

"Social impact assessment can be defined as the process of assessing or estimating the social consequences that are likely to follow specific policy actions or project development, particularly in the context of appropriate national, state, or provincial environmental policy legislation" [8]. The objective of SIA is to identify the intended and unintended effects of planned interventions to develop sustainable management plans" [7]. Therefore, impact assessment is a process analyzing the positive and negative consequences of an activity, plan, or project on the environment. The particular aim of the assessment is to provide an information to decision makers allowing them to introduce environmental and social protection considerations in decision-making process. Studies have presented a general classification of different social impacts which are needed to be considered in SIA and many studies have tried to modify these classifications $[6,25,27,35,39]$.

Interorganizational Committee on Principles and Guidelines for social impact assessment 18] defines social impacts of plans under five headings including population change, community and institutional structures, political 
and social resources, community and family changes, and community resources. According to Vanclay [40], "SIA is an umbrella or overarching framework that encompasses all human impacts including aesthetic (landscape analysis), archaeological and heritage, community, cultural, demographic, development, economic and fiscal, gender, health, indigenous rights, infrastructure, institutional, political (human rights, governance, democratization etc.), poverty-related, psychological, resource issues (access and ownership of resources), the impacts of tourism and other impacts on societies. SIA is not limited to a narrow or restrictive understanding of the concept 'social.'

Schooten et al. [37] provided a comprehensive list of social changes resulting from development plans and technology diffusion including health and social wellbeing, quality of the living environment (livability), economic impacts and material well-being, cultural impacts, family and community impacts, institutional, legal, political and equity impacts as well as gender relations. Due to the Guidelines of Iran's Department of Environment, four categories of impacts should be studied in the scoping stage: impacts on physical, natural, and socio-cultural environments, and on development plans. Physical environment relates to land, water, air, and soil. Natural environment includes plant and animal species, habitats, landscapes, and bird migration routes. The impacts on development plans refer to the impact of the proposed activities on other agricultural, industrial, or service developments taking place in the region. Finally, impacts on the socio-cultural environment include people's health, employment, housing, education, religious and cultural belief as well as cultural heritage [2].

The purpose of this paper is technical, social, economic, and environmental impacts' assessment of laserland-leveling project in Fars Province, Iran, comparing the impacts from the viewpoints of farmers' adopting traditional-leveling (adopters of previous land-leveling technology) and laser-land-leveling projects and identifying factors influencing perception of adopters of traditional-leveling towards laser-land-leveling technology impacts to persuading them to accept laser-land-leveling technology.

\section{Scope of the study}

This study is carried out in Fars Province, Iran. The main part of water annual productions of Iran belongs to Fars Province which includes $11.83 \%$ of the water level of the country. About $9.7 \%$ of total agricultural products are at this level [12]. Climate variation, agricultural farming lands' expansion, the existence of long records, and scientific centers of agriculture provide acceptable status in the agriculture of this province and an appropriate capability for developing agricultural activities qualitatively and quantitatively. Based on the high level of water products in this province and water crisis, Fars Province is one of the pioneers in introducing and applying of laserland-leveling technology in Iran from 2004 on 6 hectares to 2016 on 225,000 [12]. The geographical status of this province is shown in Fig. 1.

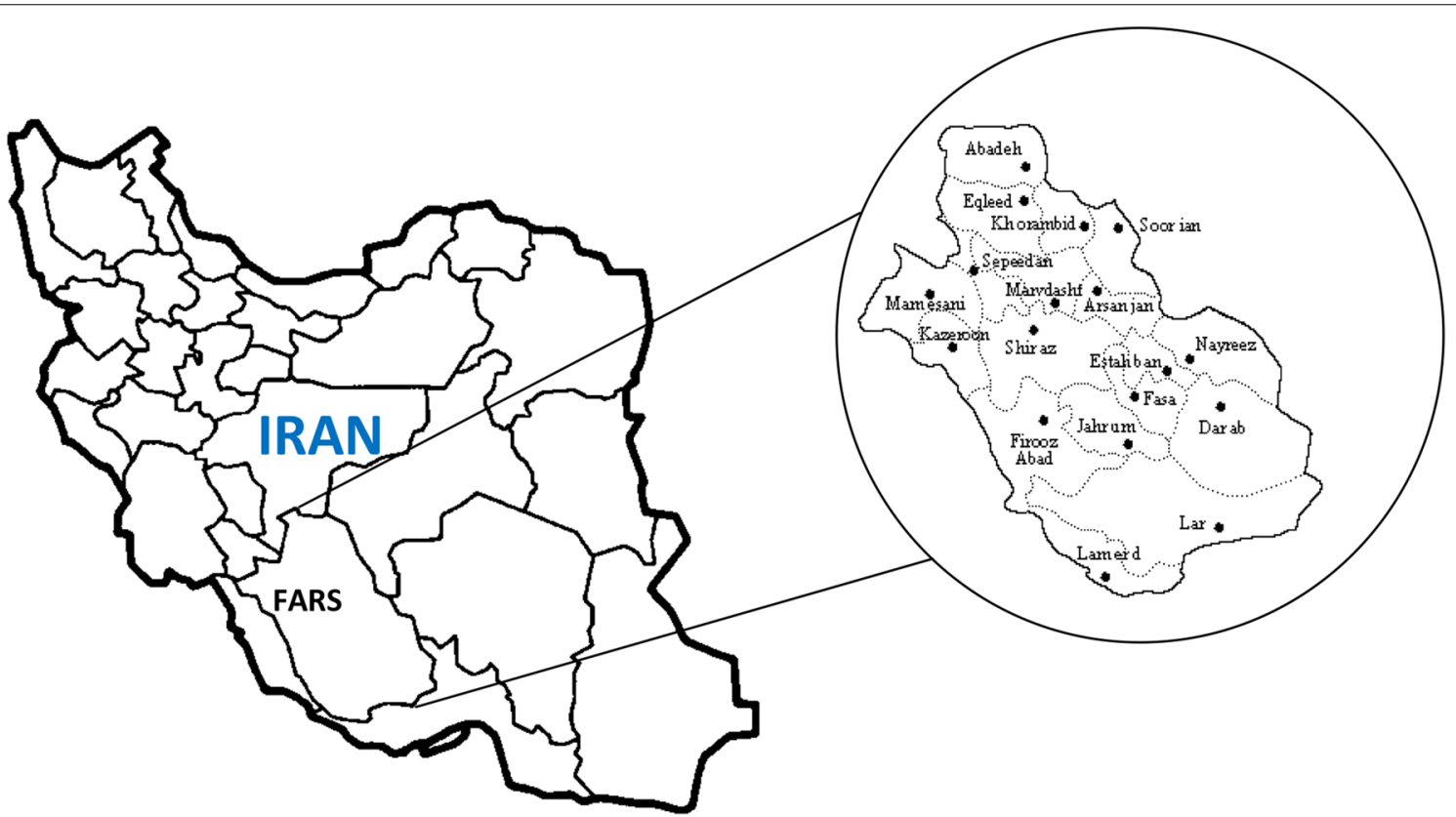

Fig. 1 Location of the study area 


\section{Research method}

The research draws on a mixed-methods approach. At first, the impacts of laser-land leveling were taken into consideration among adopters of laser-land leveling and traditional-land leveling using the survey method and then the qualitative method using the case study to complement the results of the quantitative stage.

\section{Quantitative stage}

Statistical population in this study (5600 farmers) includes all farmers adopting laser-land leveling and traditional-land leveling (excavation and embankment "cut and fill" are carried out by tractor-scraper with optical and mechanical methods) and domiciled at Fars Province. Stratified random sampling was used to select the sample. The adopters were considered as two strata of adopters of laser-land leveling and adopters of traditional-land leveling. First, nine counties were selected randomly among the 29 counties of Fars province which both kinds of laser leveling were applied by the farmers. Then, 41 villages were chosen in these nine counties at random. Afterwards, 375 farmers were selected as a research sample due to Cochran's formula (Eq. 1) [13]. The farmers were chosen randomly among two groups of adopters as well as considering the total farmers of each village. Finally, 258 farmers out of 4000 (laser-land-leveling adopters) and 117 out of 1600 (traditional-land-leveling adopters) were selected for interviews:

$$
n=\frac{N(t \cdot s)^{2}}{N d^{2}+(t \cdot s)^{2}} \text {. }
$$

The validity and reliability of questionnaire were confirmed by the professors of Shiraz University and conducting a pilot study, 32 farmers out of the main sample in Arsanjan county of Fars Province, respectively. After the pilot study, the questionnaire was edited. Cronbach's alpha coefficients confirmed the reliability of variables (Table 1). Data were analyzed using SPSS and EQS statistical software, version 19 and 6.1, respectively.

Table 1 Cronbach's alpha coefficients of research variables

\begin{tabular}{ll}
\hline Variables & $\begin{array}{l}\text { Cronbach's } \\
\text { alpha } \\
\text { coefficients }\end{array}$ \\
\hline Knowledge of laser-land leveling & 0.70 \\
Access to information of laser-land leveling & 0.70 \\
Attitude towards prior projects & 0.80 \\
Attitude towards water and soil conservation & 0.72 \\
Well-being & 0.73 \\
Social capital & 0.74 \\
Conflict between farmers & 0.83 \\
Impacts of laser-land-leveling project & 0.95 \\
\hline
\end{tabular}

\section{Definition of variables \\ Knowledge of laser-land leveling}

This variable was measured the farmers' information regarding activities required for laser-land leveling, benefits of laser-land leveling and farmers' understanding about land management, before and after the laser-landleveling implementation.

\section{Attitude towards prior projects}

It was estimated by the items related to farmers` satisfaction level as well as their opinion about the prior development plans that have been implemented in their villages (including poverty and income status, monitoring, participation, etc.)

\section{Access to information of laser-land leveling}

This variable refers to the farmers' access to laser-landleveling information resources such as radio and TV programs, extension programs, contact with experts, extension publications, etc.

\section{Social capital}

Social capital is defined as a set of informal value or common norms between members of a group that provide the basis for co-operation between them [4]. This variable was measured by the items including social norms, social trust, information flow, and institutional trust [23].

\section{Attitude towards water and soil conservation}

It was measured by the items related to farmers' opinions about the water and soil resources conservation, the importance of these resources, surface and groundwater quality as well as learning about water and soil conservation, etc.

\section{Well-being}

This variable was estimated by the items such as improving the individual's living conditions, quality of life, life satisfaction, life and entertainment enjoy, and spending time with family.

\section{Conflict between farmers}

It was measured based on the amount of conflicts and disputes in the village, the rate of co-operation between rural people, and the degree of co-ordination of them.

\section{Impacts of laser-land leveling}

To determine the impacts of laser-land leveling, 79 questions were posed in the fields of technical, social, economical, and ecological impacts. The list of items was provided through three steps. In the first step, information related to the impacts of laser-land leveling was gathered based on documents and related 
studies. In the second step, a pre-pilot study was done on six pioneer farmers domiciled in Zarghan and Marvdasht counties of Fars province (Iran) to confirm the impacts of laser-land-leveling using personal interviews. In the last step, six experts of Mechanization Departments and Water and Soil Department of Agriculture Jihad Organization of Fars Province were interviewed as the project managers. Eventually, findings of the last step were conceptualized with percentage and frequency as indices for the impacts of the technology.

\section{Qualitative stage}

In the qualitative stage, a protocol consisting of open questions was designed. In this stage, two villages, Aliabad and Sheikh Obood from Sepidan Counties, were selected as a research area. The farmers of these villages have been adopting laser-land leveling in their farms since 2006. Purposeful sampling, participatory assessment technique, and snowball methods were used for samples selection. At first, the list of laserland-leveling and traditional-land-leveling adopters was prepared. Afterwards, villages were inspected and the first interviewee was determined by inquiring villagers, council members, and rural administrators. Through inquiring, the next adopters were sequentially selected and interviewed. The criteria for selecting the samples were knowledge of the farmers in land leveling and agricultural activities, the year of adoption of land leveling, individuals' expressions, and their willingness for participation. This process lasted to theoretical saturation. In this phase, 27 farmers were interviewed including 22 laser-land-leveling adopters and 5 traditional-land-leveling performers. The methodology flowchart is shown in Fig. 2.

\section{Results and discussion}

\section{Technical impacts}

In Table 2, frequencies and mean rank are shown for technical impacts of laser-land-leveling project. As shown in the table, farmers considered uniform germination of the crop (mean rank, 2.69) as the most important technical and agronomical impact. In addition, $74.1 \%$ of farmers have assessed that the impact of laser-land leveling on uniform germination is high and only $1.6 \%$ believed that laser-land leveling has no impact on uniform germination. Therefore, from the qualitative phase, the farmers stated that: "where the land is even and soil has uniform moisture, seeds would receive equal moisture and would be planted in the same depth and germinated together." The results are consistent with the results of Abdullaev et al. [1] and Jat et al. [19].

The results of Table 2 show that uniform distribution of water (mean rank, 2.68) is located in the second rank after uniform germination. In a way that $70.4 \%$ of farmers stated that laser-land leveling impact on the uniform distribution of water was high and $25.6 \%$ of the farmers' ranked average. None of the farmers considered that laser-land leveling had no impact on the uniform distribution of water in the farm. The farmers cited this in the qualitative stage: "laser land leveling was so accurate that resulted in uniform water distribution in the farm. Before land leveling, lower parts were wet and higher ones were dry but now all parts of the farm are irrigating uniformity." These findings corroborated the studies of Das et al. [9], Shahani et al. [36], Abdullaev et al. [1], Jat et al. [19], and Asif et al. [5].

In addition, $70.4 \%$ of the farmers believed that laserland leveling will facilitate agricultural activities highly and just $0.5 \%$ of them are on the belief that laser-land

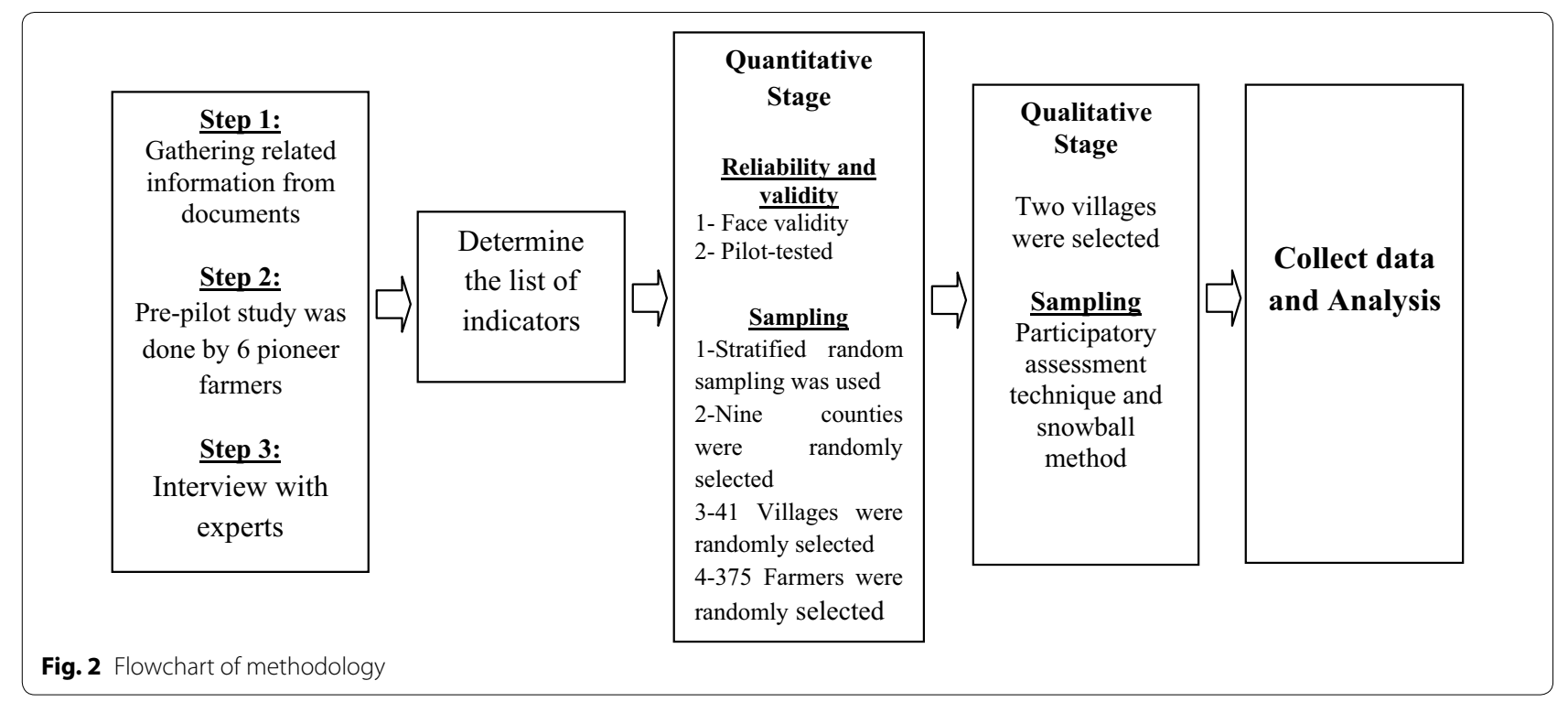


Table 2 Technical impacts of laser-land-leveling technology

\begin{tabular}{|c|c|c|c|c|c|c|c|c|c|}
\hline \multirow[t]{3}{*}{ Variables } & \multicolumn{6}{|c|}{ Positive impact } & \multirow{2}{*}{\multicolumn{2}{|c|}{ No impact }} & \multirow[t]{3}{*}{ Mean rank } \\
\hline & \multicolumn{2}{|l|}{ High } & \multicolumn{2}{|l|}{ Medium } & \multicolumn{2}{|l|}{ Low } & & & \\
\hline & Percent & Frequency & Percent & Frequency & Percent & Frequency & Percent & Frequency & \\
\hline Uniform germination of crop & 74.1 & 278 & 22.1 & 83 & 1.6 & 6 & 1.6 & 6 & 2.69 \\
\hline Uniform distribution of water & 70.4 & 264 & 25.6 & 96 & 2.7 & 10 & - & - & 2.68 \\
\hline Facilitating agricultural activities & 70.4 & 264 & 25.1 & 94 & 3.2 & 12 & 0.5 & 2 & 2.66 \\
\hline Water waste & 73.1 & 274 & 17.9 & 67 & 6.9 & 26 & 1.1 & 4 & 2.64 \\
\hline Uniform growth of crop & 69.3 & 260 & 26.1 & 98 & 2.4 & 9 & 1.6 & 6 & 2.64 \\
\hline Water consumption & 65.9 & 247 & 30.4 & 114 & 2.4 & 9 & 0.5 & 2 & 2.62 \\
\hline Irrigation time & 65.1 & 244 & 30.4 & 114 & 2.9 & 11 & 0.5 & 2 & 2.61 \\
\hline Cultivation in barren lands & 67.7 & 254 & 24.8 & 93 & 3.5 & 13 & 2.7 & 10 & 2.59 \\
\hline Land consolidation & 67.7 & 254 & 24.5 & 92 & 3.2 & 12 & 3.2 & 12 & 2.58 \\
\hline Crop yield & 59.5 & 223 & 35.5 & 133 & 2.4 & 9 & 1.6 & 6 & 2.54 \\
\hline Machineries speed (time-saving) & 63.2 & 237 & 28.5 & 107 & 5.3 & 20 & 2.1 & 8 & 2.54 \\
\hline Expansion of total area planting & 61.9 & 232 & 28.3 & 106 & 5.6 & 21 & 2.9 & 11 & 2.51 \\
\hline Cretes sizes & 61.1 & 229 & 30.4 & 114 & 4.5 & 17 & 2.9 & 11 & 2.51 \\
\hline $\begin{array}{l}\text { Improving machineries traverse } \\
\text { (improving field trafficability) }\end{array}$ & 60.8 & 228 & 29.6 & 111 & 6.1 & 23 & 2.7 & 10 & 2.49 \\
\hline Deep percolation of water & 62.1 & 233 & 25.9 & 97 & 6.9 & 26 & 3.7 & 14 & 2.48 \\
\hline Using conservation tillage & 57.3 & 215 & 31.2 & 117 & 5.6 & 21 & 2.7 & 10 & 2.47 \\
\hline Using chopper combine & 54.9 & 206 & 26.7 & 100 & 5.1 & 19 & 3.5 & 13 & 2.47 \\
\hline Traffic of tractor in the field & 61.9 & 232 & 26.7 & 100 & 6.9 & 26 & 3.7 & 14 & 2.47 \\
\hline Cultivable area (farm useful area) & 55.2 & 207 & 36.5 & 137 & 5.3 & 20 & 2.1 & 8 & 2.45 \\
\hline Using zero tillage planting & 65.9 & 247 & 30.4 & 114 & 2.4 & 9 & 0.5 & 2 & 2.41 \\
\hline Using modern solutions sprayer & 57.1 & 214 & 27.2 & 102 & 5.3 & 20 & 6.4 & 24 & 2.40 \\
\hline Time taken for land preparation & 54.9 & 206 & 32.3 & 121 & 6.1 & 23 & 5.1 & 19 & 2.39 \\
\hline Combination use & 56.3 & 211 & 29.1 & 109 & 7.2 & 27 & 5.1 & 19 & 2.39 \\
\hline Tillage operation & 49.3 & 185 & 38.7 & 145 & 6.7 & 25 & 3.7 & 14 & 2.35 \\
\hline Time taken for harvesting & 54.9 & 206 & 31.7 & 119 & 5.1 & 19 & 7.5 & 28 & 2.35 \\
\hline Density of crop & 53.1 & 199 & 34.1 & 128 & 5.6 & 21 & 6.1 & 23 & 2.35 \\
\hline Cropping pattern & 57.3 & 215 & 27.5 & 103 & 4.8 & 18 & 8.8 & 33 & 2.35 \\
\hline Coping with drought & 53.1 & 199 & 31.7 & 119 & 8.3 & 31 & 5.6 & 21 & 2.34 \\
\hline Crop shedding & 57.3 & 215 & 26.9 & 101 & 5.3 & 20 & 8.8 & 33 & 2.34 \\
\hline Moisture-holding capacity & 51.2 & 192 & 35.7 & 134 & 4.3 & 16 & 7.5 & 28 & 2.32 \\
\hline Farm infrastructures & 52.8 & 198 & 30.1 & 113 & 5.9 & 22 & 9.9 & 37 & 2.27 \\
\hline Time taken for planting & 50.7 & 190 & 32.8 & 123 & 5.3 & 20 & 10.1 & 38 & 2.25 \\
\hline Underground waters level & 50.1 & 188 & 31.7 & 119 & 7.2 & 27 & 9.6 & 36 & 2.24 \\
\hline Fossil fuel consumption & 43.5 & 163 & 35.2 & 132 & 10.1 & 38 & 5.6 & 21 & 2.23 \\
\hline Crop diversity & 49.3 & 185 & 32.0 & 120 & 6.1 & 23 & 11.5 & 43 & 2.20 \\
\hline Crop rotation & 45.1 & 169 & 34.7 & 130 & 5.6 & 21 & 12.5 & 47 & 2.14 \\
\hline Frequency of irrigation & 46.4 & 174 & 31.7 & 119 & 8.5 & 32 & 12.3 & 46 & 2.13 \\
\hline Land fallow & 46.7 & 175 & 30.1 & 113 & 6.4 & 24 & 15.7 & 59 & 2.08 \\
\hline Electricity use & 42.7 & 160 & 32.5 & 122 & 5.9 & 22 & 15.2 & 57 & 2.06 \\
\hline Seed consumption & 40.3 & 151 & 36.0 & 135 & 8.3 & 31 & 14.4 & 54 & 2.03 \\
\hline Irrigation method & 47.5 & 178 & 24.5 & 92 & 3.2 & 12 & 23.5 & 88 & 1.97 \\
\hline Pesticide consumption & 30.9 & 116 & 35.7 & 134 & 9.6 & 36 & 23.2 & 87 & 1.74 \\
\hline Fertilizer consumption & 27.5 & 103 & 35.5 & 133 & 9.3 & 35 & 26.7 & 100 & 1.64 \\
\hline Number of spraying pesticides & 26.1 & 98 & 33.1 & 124 & 8.3 & 31 & 31.5 & 118 & 1.54 \\
\hline Harvest date & 27.2 & 102 & 27.5 & 103 & 8.8 & 33 & 35.2 & 132 & 1.47 \\
\hline
\end{tabular}


Table 2 (continued)

\begin{tabular}{|c|c|c|c|c|c|c|c|c|c|}
\hline \multirow[t]{3}{*}{ Variables } & \multicolumn{6}{|c|}{ Positive impact } & \multirow{2}{*}{\multicolumn{2}{|c|}{ No impact }} & \multirow[t]{3}{*}{ Mean rank } \\
\hline & \multicolumn{2}{|l|}{ High } & \multicolumn{2}{|l|}{ Medium } & \multicolumn{2}{|l|}{ Low } & & & \\
\hline & Percent & Frequency & Percent & Frequency & Percent & Frequency & Percent & Frequency & \\
\hline $\begin{array}{l}\text { Turnaround time between har- } \\
\text { vesting one crop and planting } \\
\text { another }\end{array}$ & 24.8 & 93 & 24.0 & 90 & 8.0 & 30 & 40.5 & 152 & 1.33 \\
\hline Planting date & 22.4 & 84 & 23.5 & 87 & 7.5 & 28 & 45.9 & 172 & 1.22 \\
\hline Yielding period length & 20.3 & 76 & 21.9 & 82 & 5.9 & 22 & 48.8 & 183 & 1.14 \\
\hline
\end{tabular}

leveling has no impact on facilitating such activities. The mean rank of facilitating agricultural activates due to performing laser-land leveling is 2.66. In this respect, farmers said: "when a land with low and high parts was not useful for so long it led to problems".

The results revealed that mean rank of reducing water waste, uniform growth of the crop, decreasing water consumption, and irrigation time were 2.64, 2.64, 2.62, and 2.61, respectively. Decreasing water consumption, irrigation time, and water waste were among the most important impacts of this project in Iran as a result of water shortage crisis. Farmers emphasized these impacts in the qualitative phase. They stated that: "about 50 percent of water consumption was cut down". "Before laser land leveling water waste was high due to being low and high and improper slope" and "water flow forward was doubled". The results of Gonzalez et al. [16]; Abdullaev et al. [1], Jehangir et al. [22], Jat et al. [19], Asif et al. [5] and Rickman [31] confirmed these findings.
Furthermore, 53.1\% of farmers believed that laser-land leveling contributed them during the drought period in Iran to decrease the damages resulting from drought. Based on the results in Table 2, 48.8\% of farmers evaluated that the laser-land leveling has no impact on the length of the yielding period. This technical result of laser-land leveling has the least value by obtaining rank mean equal to 1.14 and it is stipulated less than other technical issues presented in this research. In addition, $45.9 \%$ of the farmers believed that laser-land leveling would not change the planting date. Thus, this finding with the mean of 1.22 evaluated less, as one of the impacts of laser-land leveling by farmers. Other technical impacts are shown in Table 2.

\section{Ecologic impacts}

Results in Table 3 indicate that soil erosion and fertility (mean rank, 2.47) are presented as the most significant impacts of laser-land leveling. The results of distributing these two impacts show that $60.5 \%$ of farmers have assessed the impact of laser-land leveling on increasing

Table 3 Ecological impacts of laser-land-leveling technology

\begin{tabular}{|c|c|c|c|c|c|c|c|c|c|}
\hline \multirow[t]{3}{*}{ Variables } & \multicolumn{6}{|c|}{ Positive impact } & \multicolumn{2}{|c|}{ No impact } & \multirow[t]{3}{*}{ Mean rank } \\
\hline & \multicolumn{2}{|l|}{ High } & \multicolumn{2}{|l|}{ Medium } & \multicolumn{2}{|l|}{ Low } & \multirow[t]{2}{*}{ Percent } & \multirow[t]{2}{*}{ Frequency } & \\
\hline & Percent & Frequency & Percent & Frequency & Percent & Frequency & & & \\
\hline Soil erosion & 59.5 & 223 & 30.4 & 114 & 5.3 & 20 & 3.7 & 14 & 2.47 \\
\hline Soil fertility & 60.5 & 227 & 29.9 & 112 & 4.0 & 15 & 4.8 & 18 & 2.47 \\
\hline Facilitated pest control & 53.3 & 200 & 32.3 & 121 & 6.1 & 23 & 7.2 & 27 & 2.33 \\
\hline Fossil fuel pollution & 52.3 & 196 & 30.7 & 115 & 5.9 & 22 & 8.8 & 33 & 2.29 \\
\hline Mixing the soil with crop residues & 52.3 & 196 & 31.2 & 117 & 8.5 & 32 & 7.2 & 27 & 2.29 \\
\hline Soil compaction & 47.7 & 179 & 35.5 & 133 & 7.7 & 29 & 8.0 & 30 & 2.24 \\
\hline Underground waters pollution & 48.3 & 181 & 32.0 & 120 & 7.5 & 28 & 9.3 & 35 & 2.22 \\
\hline Retention of crop residues & 40.8 & 153 & 34.7 & 130 & 8.3 & 31 & 13.9 & 52 & 2.04 \\
\hline Weeds density & 40.3 & 151 & 32.8 & 123 & 7.5 & 28 & 18.4 & 69 & 1.95 \\
\hline Soil salinity & 35.2 & 132 & 31.2 & 117 & 9.9 & 37 & 18.7 & 70 & 1.87 \\
\hline Beneficial insect attraction & 34.9 & 131 & 30.7 & 115 & 9.9 & 37 & 21.6 & 81 & 1.81 \\
\hline Terricolous organisms diversity & 36.3 & 136 & 26.1 & 98 & 7.5 & 28 & 25.3 & 95 & 1.77 \\
\hline
\end{tabular}


soil fertility high and just $4.8 \%$ reject this impact. Furthermore, $59.5 \%$ of farmers considered this technology on soil erosion high and $30.4 \%$ considered average. In the qualitative stage, farmers mentioned these impacts: "slope was not high now so the soil erosion was decreased by water". "laser land leveling led to increasing farm soil quality". They believed that the fertility of the soil was increased after performing laser-land leveling over time. According to their opinions, many factors affect soil fertility through laser-land leveling such as decreasing soil erosion, uniform distribution of chemical and organic fertilizers in land, reduction in consumption of chemical fertilizer, increasing in terricolous organism diversity, uniform distribution of water, crop rotation land following, plough depth decrease, soil compaction decrease, tillage operation reduction, retention of crop residues, and so on. This finding is consistent with the study carried out by Gonzalez et al. [16].

Decreasing in weeds, plant pests and diseases are among other impacts presented by the farmers in the qualitative and quantitative stages. They said that these led to decreasing pesticide application over time. The studies of Gonzalez et al. [16], Jat et al. [19], and Rickman [31] confirm these findings. In addition, farmers believed that laser-land leveling made plant residue management possible. First, since the density of crop is uniform in land level and yield is increased, the harvest of straw and stubble has been economically valuable for them. Second, farmers will harvest their previous crop earlier in laser-land level and have enough time for gathering their straw and stubble. Response of farmers to diversity of terricolous had in Table 3, and farmers said that the diversity of terricolous had the least rank mean of 1.77 as an impact of performing laser-land leveling because of invisibility of this impact. However, farmers mentioned the attraction of beneficial insects as an ecological impact of laser-land leveling in low scale and with rank mean of 1.81 .

\section{Social impacts}

Farmers take increasing competition for more productions (mean rank, 2.53) as the most important social impacts of laser-land leveling (Table 4). Obviously, $60.3 \%$ of farmers evaluated the high impact of leveling on increasing competition and $33.1 \%$ considered it average and only $2.1 \%$ believed that laser-land leveling had no impact on increasing competition for higher productions. The results showed that the second rank after the competition was given to the sense of belonging to the village with the mean rank of 2.46 . In a way that $65.6 \%$ of farmers said that the impact of laser-land leveling on increasing sense of belonging to the village was high and $20.8 \%$ evaluated that it was average. Meanwhile, most farmers believed that they were more interested in continuing their job by performing laser-land leveling. They stated: "when the land was even they had the least problems. Farmers were more interested in framing and avoided quit their jobs". As a matter of fact, laser-land leveling has reduced workload and farm costs and on the other hand farmers' income increased. Therefore, they liked their lives and jobs more than ever.

Table 4 Social impacts of laser-land-leveling technology

\begin{tabular}{|c|c|c|c|c|c|c|c|c|c|}
\hline \multirow[t]{3}{*}{ Variables } & \multicolumn{6}{|c|}{ Positive impact } & \multicolumn{2}{|c|}{ No impact } & \multirow[t]{3}{*}{ Mean rank } \\
\hline & \multicolumn{2}{|l|}{ High } & \multicolumn{2}{|l|}{ Medium } & \multicolumn{2}{|l|}{ Low } & \multirow[t]{2}{*}{ Percent } & \multirow[t]{2}{*}{ Frequency } & \\
\hline & Percent & Frequency & Percent & Frequency & Percent & Frequency & & & \\
\hline $\begin{array}{l}\text { Increasing positive competition for more } \\
\text { production }\end{array}$ & 60.3 & 226 & 33.1 & 124 & 3.2 & 12 & 2.1 & 8 & 2.53 \\
\hline $\begin{array}{l}\text { Sense of belonging to village (place } \\
\text { attachment) }\end{array}$ & 65.6 & 246 & 20.8 & 78 & 4.8 & 18 & 7.5 & 28 & 2.46 \\
\hline $\begin{array}{l}\text { Taking responsibility for improving vil- } \\
\text { lages status }\end{array}$ & 59.5 & 223 & 27.5 & 103 & 7.5 & 28 & 4.5 & 17 & 2.43 \\
\hline Interest in spending most time in village & 58.4 & 219 & 27.7 & 104 & 5.1 & 19 & 7.7 & 29 & 2.38 \\
\hline Interest in living in villages in the future & 58.7 & 220 & 25.3 & 95 & 7.5 & 28 & 7.2 & 27 & 2.37 \\
\hline Interest in farming & 41.2 & 158 & 51.7 & 194 & 4.3 & 16 & 1.1 & 4 & 2.36 \\
\hline Number of seasonal agricultural labor & 47.2 & 177 & 33.9 & 127 & 9.3 & 35 & 8.8 & 33 & 2.20 \\
\hline Number of family workforce & 36.5 & 137 & 36.0 & 135 & 10.4 & 39 & 16.0 & 60 & 1.94 \\
\hline Employment opportunities & 37.1 & 139 & 30.7 & 115 & 12.0 & 45 & 19.5 & 73 & 1.86 \\
\hline $\begin{array}{l}\text { Immigration from rural areas to urban } \\
\text { areas }\end{array}$ & 38.7 & 145 & 29.6 & 111 & 8.0 & 30 & 22.4 & 84 & 1.85 \\
\hline Immigrants returns & 26.1 & 98 & 25.1 & 94 & 11.5 & 43 & 36.3 & 136 & 1.41 \\
\hline
\end{tabular}


47.2\% of farmers believed that laser-land leveling has decreased the great number of labor required for agricultural activities. They cited that: "laser land leveling needed fewer day laborers and an active labor can do all affairs". The result was compatible with the findings of Abdullaev et al. [1] and Akhtar [3]. The results showed that $36.3 \%$ of farmers evaluated that performing laserland leveling had no impact on immigrants' returns, this social impact received the least score by obtaining the mean rank of 1.41 and it was less than other social impacts defined by the farmers.

\section{Economic impacts}

The results of Table 5 indicated that the most important economic impact defined by the farmers was income raise (mean rank, 2.23) in a way that $43.5 \%$ of the sample evaluated that the impact of laser-land leveling on raising income was high and $40.3 \%$ evaluated that it was average. In the qualitative stage, the farmers said: "when we used laser we received more incomes as our costs were reduced and our yield was increased". Farmers considered increase in total area planting, reduction of cultivation and harvest costs, cropping pattern alteration (most farmers, who leveled their lands, cultivated summer crops which its earnings were more than winter crops), work load and decreasing number of working days and thus increasing earnings from off-farm were other reasons for raising income due to performing laser-land leveling. Studies of Abdullaev et al. [1], Jat et al. [19], and Rickman [31] confirmed this finding. After income, increasing the land price with mean rank of 2.18 obtained the second rank. $46.1 \%$ of farmers evaluated laser impact on land price increase was high and $33.9 \%$ evaluated that it was average. They stated that: "In their region lands were sold based on wheat yield and soil salinity. In case that the yield was well their lands would be sold better. So laser land leveling affected the land price a lot."

A decrease in inputs and tillage costs (mean rank, 2.04) obtained the minimum rank (Table 5). However, the rank mean of the impacts was higher than 2 and the major of farmers evaluated the laser impact on reducing inputs and tillage costs as average and high.

\section{Comparing impacts between two adopter groups}

A $T$ test was used to determine whether there are any significant differences in terms of expression the impacts between two groups of adopters (Table 6). The findings showed that there was a significant difference between the means of two groups and more impacts have been presented by laser-land-leveling adopters

Table 5 Economic impacts of laser-land-leveling technology

\begin{tabular}{|c|c|c|c|c|c|c|c|c|c|}
\hline \multirow[t]{3}{*}{ Variables } & \multicolumn{6}{|c|}{ Positive impact } & \multirow{2}{*}{\multicolumn{2}{|c|}{ No impact }} & \multirow[t]{3}{*}{ Mean rank } \\
\hline & \multicolumn{2}{|l|}{ High } & \multicolumn{2}{|l|}{ Medium } & \multicolumn{2}{|l|}{ Low } & & & \\
\hline & Percent & Frequency & Percent & Frequency & Percent & Frequency & Percent & Frequency & \\
\hline Net income & 43.5 & 163 & 40.3 & 151 & 11.2 & 42 & 4.3 & 16 & 2.23 \\
\hline Land price & 46.1 & 173 & 33.9 & 127 & 8.8 & 33 & 9.6 & 36 & 2.18 \\
\hline Investment rate for farmers & 40.8 & 153 & 39.2 & 147 & 10.1 & 38 & 8.8 & 33 & 2.13 \\
\hline Labor cost & 37.1 & 139 & 41.3 & 155 & 11.5 & 43 & 8.5 & 32 & 2.08 \\
\hline Number of working days & 38.1 & 143 & 40.3 & 151 & 12.3 & 46 & 8.5 & 32 & 2.08 \\
\hline Tillage cost & 37.3 & 140 & 40.3 & 151 & 9.6 & 36 & 11.7 & 44 & 2.04 \\
\hline Inputs cost & 31.7 & 139 & 40.8 & 153 & 10.4 & 39 & 10.9 & 41 & 2.04 \\
\hline Landscape attractiveness & 65.3 & 245 & 26.9 & 101 & 2.7 & 10 & 4.3 & 16 & 2.54 \\
\hline
\end{tabular}

Table $6 \boldsymbol{T}$ test comparing means of impacts in different groups

\begin{tabular}{|c|c|c|c|c|c|c|c|}
\hline \multirow[t]{2}{*}{ Row } & \multirow[t]{2}{*}{ Variables } & \multicolumn{2}{|l|}{ Laser } & \multicolumn{2}{|c|}{ Traditional } & \multirow[t]{2}{*}{$T$ value } & \multirow{2}{*}{$\begin{array}{l}\text { Level } \\
\text { of significance }\end{array}$} \\
\hline & & Mean & $\begin{array}{l}\text { Standard } \\
\text { deviation }\end{array}$ & Mean & $\begin{array}{l}\text { Standard } \\
\text { deviation }\end{array}$ & & \\
\hline 1 & Impacts of laser-land leveling & 175.46 & 41.25 & 162.20 & 32.03 & 2.75 & 0.006 \\
\hline 2 & Ecological impacts & 28.66 & 8.40 & 25.37 & 7.46 & 3.30 & 0.001 \\
\hline 3 & Social impacts & 23.53 & 7.82 & 20.91 & 6.22 & 2.85 & 0.005 \\
\hline 4 & Economic impacts & 14.17 & 4.99 & 14.05 & 3.86 & 1.27 & 0.20 \\
\hline 5 & Technical impacts & 108.55 & 42.33 & 100.95 & 36.07 & 2.70 & 0.007 \\
\hline
\end{tabular}

The score range for total impacts, ecological impacts, social impacts, economic impacts and technical impacts are 0-237, 0-39, 0-33, 0-21, and 0-144, respectively 


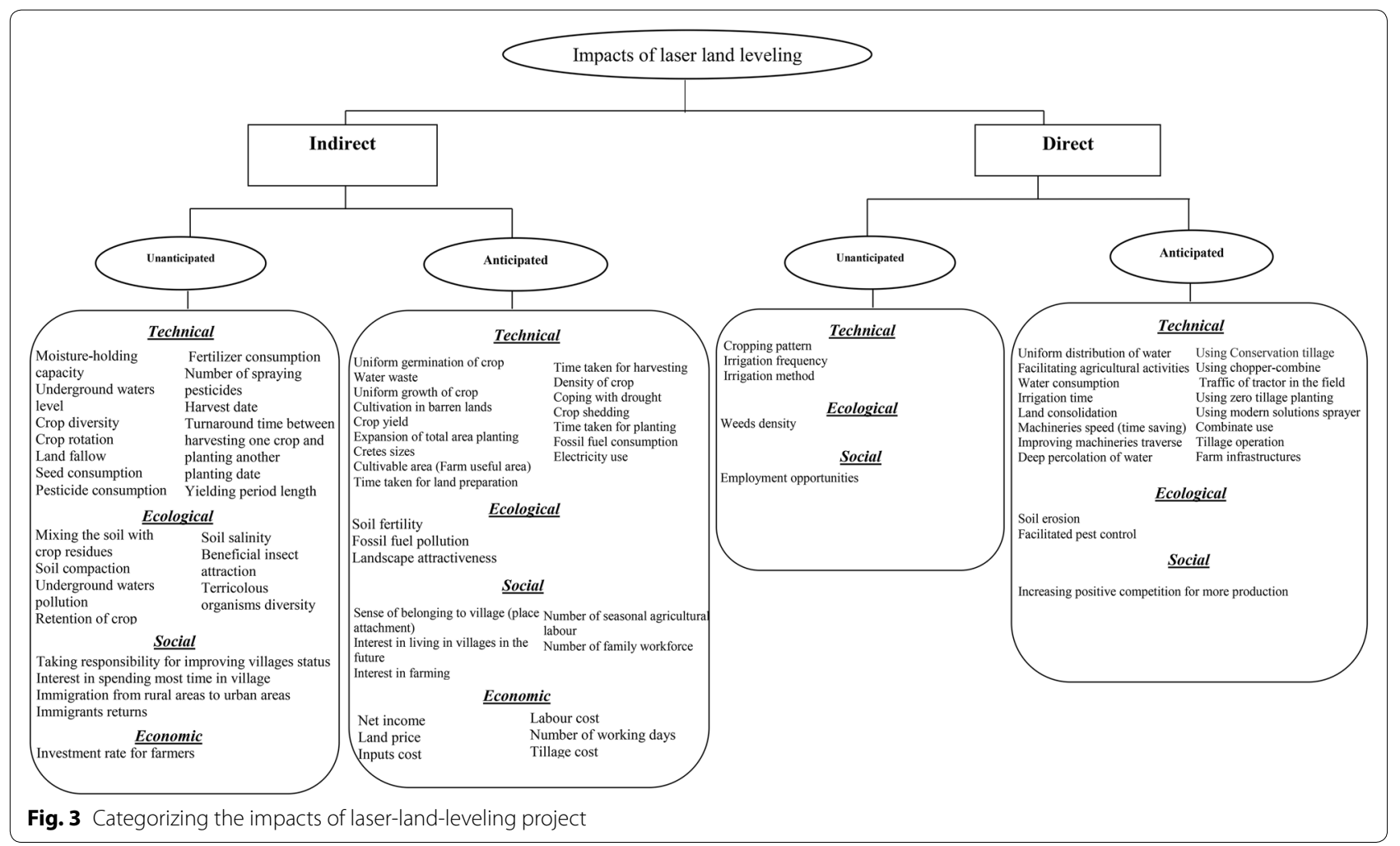

with higher mean values across the considered variables. The results of laser-land leveling ecological impacts showed that there was a significant difference between the viewpoints of both groups $(P=0.001)$ in a way that laser-land-leveling adopters defined more ecological impacts. According to Table 6, there was a significant difference between social impacts of laserland leveling and traditional-land-leveling projects $(P=0.005)$. The mean of impacts defined by laserland-leveling adopters was higher (23.53).

The mean of technical impacts of laser-land-leveling project revealed that there was a significant difference between laser-land-leveling and traditional-land-leveling adopters at the level of significance of 0.007. Adopters of laser system defined more technical impacts. However, there was no significant $(P>0.05)$ difference between the adopters' responses on economic impacts variable. According to the results, traditional-land-leveling adopters express fewer consequences for laserland leveling, because they attributed its impacts to laser-land-leveling technology. That is why they do not assess the impacts of laser-land-leveling impacts well.

\section{Categorizing impacts of laser-land-leveling project}

The impacts of the project were specified to direct or indirect, desirable or undesirable, anticipated or unanticipated. Desirable consequences are the functional effects of an innovation and undesirable consequences are the dysfunctional effects of an innovation to an individual or social system. Direct consequences are the changes to an individual or social system that occur in immediate response to an innovation and indirect consequences are the changes to an individual or social system that occur as a result of the direct consequences of an innovation. Anticipated consequences are changes brought about by an innovation that is recognized and intended by the members of a social system and unanticipated consequences are changing from an innovation that are neither intended nor recognized by the members of a social system [33]. Rogers ties all three categories together by showing each as a dimension.

Due to Rogers' category as well as the mentioned impacts by farmers, laser-land-leveling impacts could be divided in Fig. 3. By comparing the results of Fig. 3 and rank means of presented items in the study, it can be concluded that the unanticipated impacts, particularly indirect ones by the farmers, were lower than other impacts. In addition, the results revealed that most ecological impacts of the laser-land leveling were placed in the unanticipated category and the farmers concerned about technical and economic results of their behaviors and paid less attention to the ecological impacts. 
Table 7 Model evaluation overall fit measurements

\begin{tabular}{|c|c|c|}
\hline Goodness-of-fit measure & $\begin{array}{l}\text { Recommended } \\
\text { criterion }\end{array}$ & $\begin{array}{l}\text { Obtained results } \\
\text { of this research }\end{array}$ \\
\hline $\begin{array}{l}\text { Chi square/degree of freedom } \\
\left(x^{2} / d f\right)\end{array}$ & $\leq 3$ & 0.06 \\
\hline$P$-value & $\geq 0.05$ & 0.58 \\
\hline Normed fit index (NFI) & $\geq 0.90$ & 1.00 \\
\hline Non-normed fit index (NNFI) & $\geq 0.90$ & 1.18 \\
\hline Comparative fit index (CFI) & $\geq 0.90$ & 1.00 \\
\hline Goodness-of-fit index (GFI) & $\geq 0.90$ & 1.00 \\
\hline $\begin{array}{l}\text { Adjust goodness-of-fit index } \\
\text { (AGFI) }\end{array}$ & $\geq 0.90$ & 0.99 \\
\hline Root mean square residual (RMSR) & $\leq 0.05$ & 0.002 \\
\hline $\begin{array}{l}\text { Root mean square error of } \\
\text { approximation (RMSEA) }\end{array}$ & $\leq 0.1$ & 0.000 \\
\hline
\end{tabular}

Determining perception of adopters of traditional-leveling towards laser-land-leveling impacts

This section will examine the structural equation model to identify the effective factors determining traditionalleveling adopters' perception towards laser-land-leveling impacts for encouraging them to the adoption of laserland-leveling technology. EQS software was used to compute the causal effects between variables of the model including age, knowledge of laser-land leveling, access to information of laser-land leveling, level of rural development, yield, attitude towards prior projects, well-being, social capital, conflict between farmers, attitude towards water and soil resources conservation, and laser-land-leveling impacts.

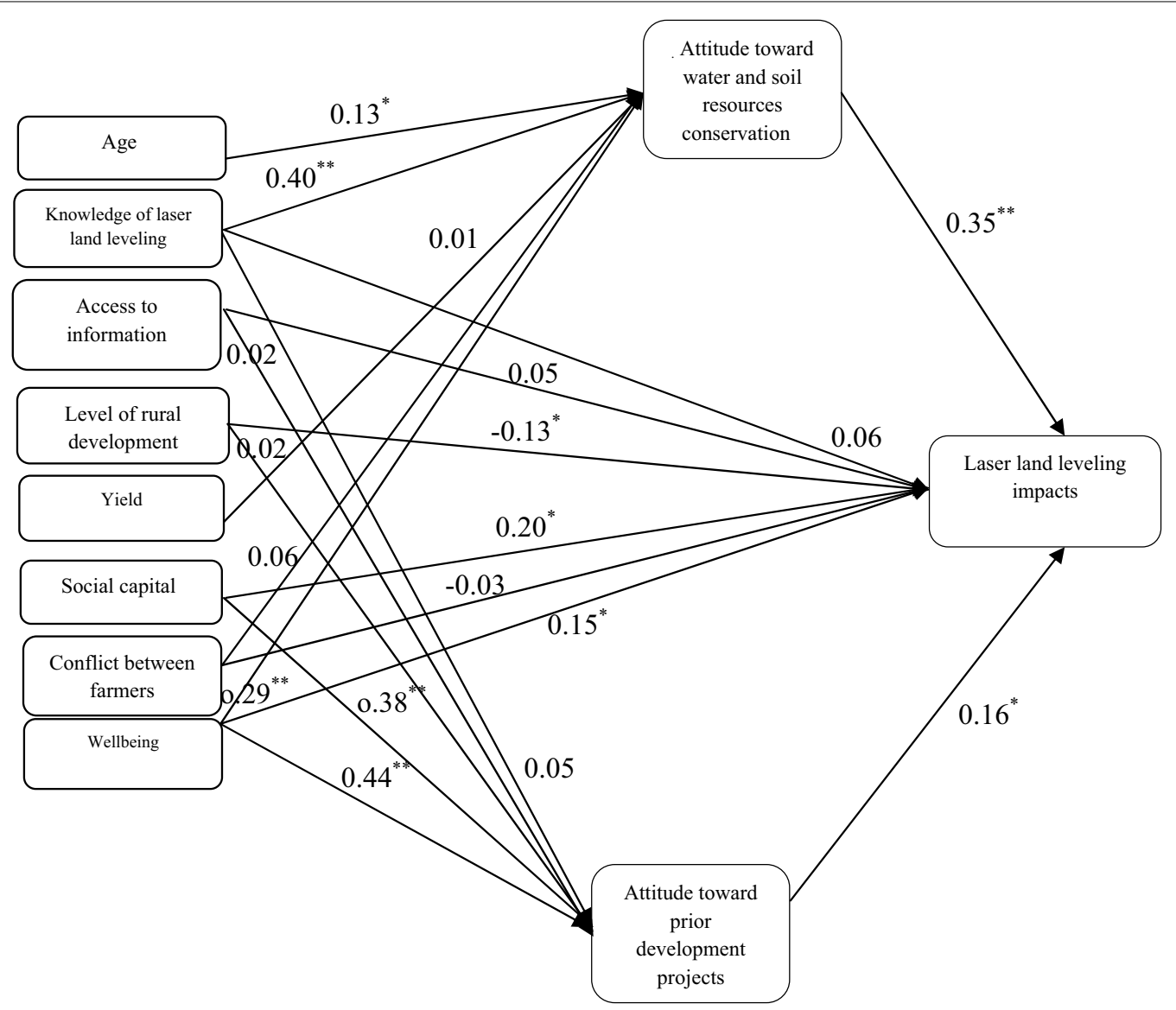

Fig. 4 Structural equation modeling and path coefficients between variables among traditional-leveling adopters 


\section{Measurement model evaluation}

According to goodness-of-fit indices, it can be said that research variables represent a suitable model for defining factors affecting laser-land-leveling project impacts from the viewpoints of farmers adopting traditional leveling (Table 7).

\section{Structural equation modeling and path coefficients}

The analysis of causal effects (Fig. 4) indicated that the knowledge of laser-land leveling had significant and positive casual effect on attitude towards water and soil resources conservation $(\lambda=0.40, P<\% 1)$. It can be stated that if the farmers have more information of activities required for soil and laser-leveling conservation, their attitude would have been improved towards resources conservation. Well-being $(\lambda=0.29, P<\% 1)$ and age $(\lambda=0.13, P<\% 5)$ are external variables which had the significant and direct effect on attitude towards water and soil resources conservation. Whenever farmers are older and have higher well-being they would have the higher attitude towards water and soil resources conservation.

The results of the study regarding the effects of independent variables on attitude towards prior development projects showed that direct effects of well-being $(\lambda=0.44, P<\% 1)$ and social capital $(\lambda=0.38, P<\% 1)$ were significant and positive. The direct effect of social capital and well-being on attitude towards prior development projects revealed that more social capital and well-being among farmers caused more positive attitude towards prior projects. This finding is corroborate with the study by Sabour et al. [34].

Attitude towards water and soil resources conservation variable had the most direct effect on laser-landleveling project impacts. The casual effect of the variable was $0.35(\beta=0.35, P<\% 1)$. Indeed, farmers with higher attitude towards water and soil resources conservation perceived laser-land-leveling project impacts more. The result is consistent with Rezaei-Moghaddam et al. [29]. Then, social capital had the most effect and its effect was significant $(\lambda=0.20, P<\% 5)$. Attitude towards prior development projects had the direct, significant and positive effect on understanding laser-land-leveling project impacts $(\beta=0.16, P<\% 5)$. The results of Tohidyan Far and Rezaei-Moghaddam [38] confirmed this finding.

Well-being had the significant and direct effect on laser-land-leveling project impacts $(\lambda=0.15, \quad P<\% 1)$. The level of rural development $(\lambda=-0.13, P<\% 5)$ was another effective variable on laser-land-leveling impacts. In general, the new technologies are often diffuse in developed areas, so most of the less developed villages remain deprivation of these technologies. Therefore, they see the smallest change in their land as a big change. Based on the results, the knowledge of land leveling and age variables had indirect effects on understanding laserland-leveling impacts through water and soil resources conservation variable.

\section{Conclusion}

This study aimed to recognize and evaluate the impacts of laser-land-leveling project. Farmers confirmed the items of quantitative in the qualitative stage. Farmers considered uniform germination of the crop, uniform distribution of water, facilitating agricultural activities, decreasing water waste, uniform growth of the crop, decreasing water consumption, and irrigation time as the most important technical and agronomical impacts of laser-land-leveling project. Hence, this technology may be presented as a strategy for managing drought and water crisis in Iran. This will come true when farmers will not expand their planting area and not changing their cropping pattern towards more water consumption. However, unfortunately, due to performing this project, farmers have often expanded their planting area and cultivated summer crops which need more water. Empowering farmers through improving attitude and change training programs in terms of water-optimized management is required and officials and decision makers should pay more attention to this issue.

Farmers stipulated the most important ecological impacts as the reduction in soil erosion, increase in soil fertility, pests decrease, decreasing fossil fuel pollution, and the possibility of crop residues management. According to ecological impacts, using laser-land-leveling technology in farm lands could be concerned in terms of environment conservation and sustainability. Most ecological impacts were unanticipated for farmers. Raising farmers' awareness by environmental training and improving their attitudes of nature and environment of living is required.

Farmers have defined the most important social impacts as increasing competition for more productions, sense of belonging to villages, taking responsibility for village status improvement, interesting in spending more time in the village, interesting in living in the village, interesting in farming, and reducing in a number of seasonal laborers. One of the impacts of project evaluated positively by farmers was reduced in a number of laborers and family workforce required for agricultural operations. However, this probably led to many social problems. If there is no opportunity to employ them in other sectors, it would result in many social and economic problems.

Raising income, increasing the land price, raise investment for farmers, and reduction in costs are among economic impacts of laser-land leveling. Based on the results from technical, ecological, economical, and social 
impacts of laser-land leveling, this technology would be useful to optimize the use of resources and sustainability of ecological, social, and economical.

Farmers' adopter of laser system recognized more ecological, social, and technical impacts than traditionalland-leveling adopters. The non-adopters of laser-land leveling had bad experience regarding traditional-land leveling and attributed it to the laser-land-leveling project due to the similarity of both technologies. As the farmers behave based on their knowledge and also the results showed that the rate of expression of unanticipated consequences was low, it is necessary to officials to increase the information of farmers regarding different consequences of the project and contributing them to make proper decisions for farm management.

In addition, this study tried to investigate key factors determining the understanding of adopters of traditional-leveling' perception towards laser-land-leveling impacts as an important step. Attitude towards water and soil resources conservation was the most important factor to anticipate the project impacts' perception among adopters of traditional leveling. It is needed to consider appropriate training courses to increase the awareness of farmers and promoting their attitudes towards conservation of basic resources especially water and soil. Social capital is a crucial element of increasing laserland-leveling impacts perception. Therefore, empowering rural people by holding workshops on social networks and relations, friendship activities, team working, and meditation are recommended. It is recommended for the future studies to study the long-term impacts of the project, particularly in relation to environmental and social aspects.

\section{Abbreviations \\ EIA: environmental impact assessment; SIA: social impact assessment; NFI: normed fit index; NNFI: non-normed fit index; CFI: comparative fit index; GFI: goodness-of-fit index; AGFl: adjust goodness-of-fit index; RMSR: root mean square residual; RMSEA: root mean square error of approximation.}

\section{Acknowledgements}

We are thankful for the agricultural extension experts and the farmers and rural people of Fars province for answering the questionnaires, patiently.

\section{Authors' contributions}

KR-M, STF: conceived and designed the experiments; contributed reagents, materials, analysis tools or data; wrote the paper. STF analyzed the data. Both authors read and approved the final manuscript.

\section{Funding}

The article has been extracted from a master thesis and a kind of student work. There is no special fund to this research.

\section{Availability of data and materials}

The data sets generated and/or analyzed during the current study are not publicly available due (because all of the data were gathered by the research team), but are available from the corresponding author on reasonable request.
Ethics approval and consent to participate I approved the ethics guideline of the journal.

\section{Consent for publication}

All of authors have informed regarding submitting the manuscript to the journal of Chemical and Biological Technologies in Agriculture.

\section{Competing interests}

The authors declare that they have no competing interests.

Received: 2 June 2019 Accepted: 6 September 2019

Published online: 19 December 2019

\section{References}

1. Abdullaev I, Hassan MU, Jumaboev K. Water saving and economic impacts of land leveling: the case study of cotton production in Tajikistan. Irrig Drain Syst. 2007;21:251-63.

2. Ahmadvand M, Karami E, Zamani GHH, Vanclay F. Evaluating the use of social impact assessment in the context of agricultural development projects in Iran. Environ Imp Assess Rev. 2009;29(6):399-407.

3. Akhtar MR. Impact of resource conservation technologies for sustainability of irrigated agriculture in Punjab-Pakistan. J Agric Res. 2006;44(3):239-57.

4. Adler P, Wookwon S. Social capital: the good, the bad and the ugly. In: lesser E, editor. Knowledge and social capital: foundations and applications. USA: Butterworth-Heinemann; 2000.

5. Asif M, Ahmed M, Gafoor A, Aslam Z. Wheat productivity, land and water use efficiency by traditional and laser land leveling techniques. J Bio Sci. 2003;3(2):141-6.

6. Burdge R. A community guide to social impact assessment. Middleton: Social Ecology Press; 1994. p. 20-69.

7. Burdge R. The practice of social impact assessment—background. Imp Assess Proj Apprais. 2003;21(1):84-8.

8. Burdge R, Vanclay F. Social impact assessment. Environ Soc Imp Assess. 1995:31-65.

9. Das A, Lad M, Chalodia A. Effect of laser land leveling on nutrient uptake and yield of wheat, water saving and water productivity. J Pharma Phytochem. 2018;7(2):73-8.

10. El-Fadel M, Zeinati M, Jamali D. Framework for environmental impact assessment in Lebanon. Environ Imp Assess Rev. 2000;20:579-604.

11. Fars Province Laser land leveling Strategic Committee. Major changes in increase inputs productivity, protect the environment and increase farmer's income with laser land leveling in 350,000 hectares of farm land in Fars Province during 5 years. 2007. p. 2-11.

12. Fars Province Laser land leveling Strategic Committee. Economical changes of laser land leveling in Fars Province. 2016. p. 12-32.

13. Fowler FJ. Survey research methods. In: Bickman L, Rog DJ, editors. Applied social research method series. USA: SAGE; 2009.

14. Gilpin A. Environmental impact assessment (EIA): cutting edge for the twenty-first century. Cambridge: Cambridge University Press; 1995. p. 23-54.

15. Glasson J, Therivel R, Chadwick A. Introduction to environmental impact assessment. 2nd edn. London: UCL Press; 1994. p. 3-76

16. Gonzalez V, Ibarraran P, Maffioli A, Rozo S. The impact of technology adoption on agricultural productivity: the case of Dominican Republic. Inter-American Development Bank: Washington D.C.; 2009. p. 33-47.

17. Gulati K, Lybbert TJ, Spielman DJ. Diffusing to level fields: evolution of laser land leveling technology markets in India. Agricultural \& applied economics association annual meeting, Chicago, Illinois, July 30-August $1,2017$.

18. Interorganizational Committee on Principles and Guidelines for Social Impact Assessment. Guidelines and principles for social impact assessment. Imp Assess. 2003;12(2):107-12.

19. Jat ML, Chandna P, Gupta R, Sharma SK, Gill MA. Laser land leveling: a precursor technology for resource conservation. In: Rice-Wheat consortium technical bulletin series 7. New Delhi, India; 2006. p. 2-18.

20. Jat ML, Sharma SK, Gupta R, Sirohi K, Chandana P. Laser land leveling: a precursor technology for resource conservation in irrigated ecosystem of India. In: Conservation agriculture-status and prospects. 2005; p. 1-23. 
21. Jay S, Jones C, Slinn P, Wood C. Environmental impact assessment: retrospect and prospect. Environ Imp Assess Rev. 2007;27:287-300.

22. Jehangir WA, Masih I, Ahmed S, Gill MA, Ahmad M, Mann RA, Chaudhary MR, Qureshi AS, Turral H. Sustaining crop water productivity in rice-wheat systems of south Asia: a case study from Punjab, Pakistan. Colombo: International Water Management Institute; 2007. p. 3-22.

23. Jiyoung Kim, M.S. Effects of institutional environment and social capital on rural consumers' inshopping behavior. Ph. D. thesis. The Ohio state university. 2008

24. Joao E. How scale affects environmental impact assessment. Environ Imp Assess Rev. 2002;22:289-310.

25. Juslen J. Social impact assessment: a look at finish experiences. Proj Apprais. 1995;10(3):163-70.

26. Kalantari $\mathrm{KH}$, Abdollahzadeh Gh. Factors affecting land fragmentation in Iran: a case study of Ramjerd Sub District in Fars province. Am J Agric Biol Sci. 2008;3(1):358-63.

27. McCracken J, Narayan D. Participation and social assessment: tools and techniques. Washington: The International Bank for Reconstruction and Development; 1998. p. 3-19.

28. Memari A, Soleimani S. Measuring environmental impacts of Tabatak dam in Khorasan Razavi Province. In: International Seminar of River Engineering. Ahvaz: Chamran University. 2006; p. 18-53.

29. Rezaei-Moghaddam K, Karami E, Gibson J. Conceptualizing sustainable agriculture: Iran as an illustrative case. J Sustain Agric. 2005;27(3):25-56.

30. Rezaei-Moghaddam K, Karami E. Developing a green agricultural extension theory. Int J Sustain Dev Plan. 2008;3(3):242-56.

31. Rickman JF. Manual for laser land leveling. In: Rice-Wheat Consortium Technical Bulletin. 2002; p. 1-13.

32. Rodrigues GS, Campanhola C, Kitamura PC. An environmental impact assessment system for agricultural R\&D. Environ Imp Assess Rev. 2003;23:219-44.
33. Rogers EM. Diffusion of innovation. 4th ed. New York: The Free Press; 1995. p. 70-102.

34. Sabour F, Rezaei-Moghaddam K, Menatizadeh M. Factors influencing adoption of Soil conservation practices among farmers in Garmsar County. 2017;13(1):59-73.

35. Sairinen R. Assessing social impacts of urban land- use plans: from theory to practice. Bor Environ Res. 2004;9:509-17.

36. Shahani WA, Kaiwen F, Memon A. Impact of laser leveling technology on water use efficiency and crop productivity in the cotton-wheat cropping system in Sindh. Int J Res. 2016;4(2):220-31.

37. Schooten M, Vancly F, Slootweg M. Conceptualising social change processes and social impacts. In: Becker HA, Vanclay F, editors. The International handbook of social impact assessment: conceptual and methodological advances. Cheltenham: Edward Elgar Publishing; 2003. p. 74-91.

38. Tohidyan Far S, Rezaei-Moghaddam K. Laser land levelling as a strategy for environmental management: the case of Iran. Pollution. 2015;1(2):203-15.

39. Vanclay F. International principles for social impact assessment. Imp Assess Proj Apprais. 2003;21(1):5-11.

40. Vanclay F. Conceptualising social impact. Environ Imp Assess Rev. 2002;22(3):183-211.

\section{Publisher's Note}

Springer Nature remains neutral with regard to jurisdictional claims in published maps and institutional affiliations.

\section{Submit your manuscript to a SpringerOpen ${ }^{\circ}$ journal and benefit from:}

- Convenient online submission

- Rigorous peer review

- Open access: articles freely available online

- High visibility within the field

- Retaining the copyright to your article

Submit your next manuscript at springeropen.com 